\title{
A Comparative Investigation of the Impact of Effective Online Teaching Strategies Practiced during Corona Pandemic in Ensuring Sustainable Pedagogy
}

\author{
Choudhary Zahid Javid", Naif Saad Althobaiti, Eidah Abdullah Al-Malki \\ Department of Foreign Languages, College of Arts, Taif University, Taif, Saudi Arabia
}

Received September 3, 2020; Revised November 25, 2020; Accepted December 1, 2020

\section{Cite This Paper in the following Citation Styles}

(a): [1] Choudhary Zahid Javid, Naif Saad Althobaiti, Eidah Abdullah Al-Malki , "A Comparative Investigation of the Impact of Effective Online Teaching Strategies Practiced during Corona Pandemic in Ensuring Sustainable Pedagogy," Universal Journal of Educational Research, Vol. 9, No. 1, pp. 17 - 31, 2021. DOI: 10.13189/ujer.2021.090103.

(b): Choudhary Zahid Javid, Naif Saad Althobaiti, Eidah Abdullah Al-Malki (2021). A Comparative Investigation of the Impact of Effective Online Teaching Strategies Practiced during Corona Pandemic in Ensuring Sustainable Pedagogy. Universal Journal of Educational Research, 9(1), 17 - 31. DOI: 10.13189/ujer.2021.090103.

Copyright $\odot 2021$ by authors, all rights reserved. Authors agree that this article remains permanently open access under the terms of the Creative Commons Attribution License 4.0 International License

\begin{abstract}
This survey reports results and findings related to the perceptions of English language teachers from Gulf universities pertaining to the impact of effective online strategies practiced during corona pandemic. A validated self-developed 5-point survey instrument has been used to collect data for this comparative investigation. The instrument was pilot tested after determining its content validity and reliability. Cronbach alpha $(\alpha)$ reliability test was run to determine reliability. The final version of the questionnaire consisting of 51 items was generalized and uploaded on Google forms to record the participants' responses. One hundred forty-four responses were recorded including $94(\mathrm{n}=94)$ from Saudi universities and fifty $(n=50)$ from other Gulf countries including UAE, Bahrain, Oman and Kuwait. The participants of the study have seen eye to eye with each other in majority of questionnaire items and ranked 'asking comprehension questions', teacher-student interaction' and 'teachers' oral feedback' as the most preferred teaching strategies in enhancing content understanding, students' motivation, mutual interaction, teacher-student rapport and active engagement in learning. The findings have also revealed that lecturing, written assignments, individual projects have been perceived least effective teaching strategies in producing positive results during online teaching. Among the most important pedagogical skills needed to deliver successful online courses, 'communication skills' and 'patience' have been perceived
\end{abstract}

the most effective. The remaining skills have also been assigned high mean values indicating their positive role in online teaching. Results generated by independent-samples T-test have accepted 6 null hypotheses and rejected one hypothesis. Findings and recommendations have been presented based on the results of this survey.

Keywords Corona Pandemic, Innovative Teaching Practices, On-line Teaching, Face-to-Face Teaching, Sustainable Teaching

\section{Introduction}

\subsection{Background of the Study}

The pandemic of corona virus has been on the rise around the world and its effects have changed the normal life in all countries. It has been reported that WHO declared covid-19 as 'a global public health emergency' on 30-1-2020, called for an immediate international concern and on 11-3-2020, it was declared as a pandemic by Cucinotta \& Vanelli [1]. This all-encompassing change and its impact have been phenomenal in term of maintaining social distancing and educational organizations have also suffered from its negative impact. It has also been reported that like all other walks of life, 
corona pandemic has inflicted serious impact on various stake holders of educational circles including the faculty members, students and educational institutions [2]. As a compulsory safety measure to combat this pandemic, educational institutions of all levels including schools, colleges and universities were closed down putting all educational activities on campus at halt throughout the world [3]. Basilaia \& Kvavadze [4] have reported that "different countries worldwide have introduced various solutions during the pandemic to continue the education process. Online libraries, TV broadcasts, guidelines, resources, video lectures, online channels were introduced in at least 96 countries" (p. 1). Saudi Arabia and other Gulf countries have also followed suit and opted non-conventional mode of teaching including on-line education to avoid social contact on campuses to fight this battle against corona pandemic. Saudi ministry of education has announced closure of all public and private schools, technical and vocational training institutions and universities across Saudi Arabia from March $9^{\text {th }}$ as a "preventive and precautionary" measure recommended by the health authorities to protect students and staff. Simultaneously, it has been announced that "the Minister of Education directed that virtual schools and distance education be activated while the schools are closed to ensure that the educational process continues in an effective and quality manner" [5]. The gravity of the situation is evident from the announcement issued by UNESCO 'Covid-19 Educational Disruption and Response' monitoring agency that "as of 13 April 2020, approximately 1.725 billion learners have been affected due to school closures in response to the pandemic." It has also been reported that "192 countries have implemented nationwide closures and 5 have implemented local closures, impacting about 99.9 percent of the world's student population" [6]. The report has also recommended to use distance learning programs including open educational applications and platforms instead of face to face teaching to ensure continuity of teaching process.

It has been stated that educational institutions were slow in adopting much sought-after online teaching platforms and resorted to traditional lecture-based and classroom-based pedagogy. The recent tragedy of "COVID-19 has become an opportunity and a catalyst for educational institutions worldwide to search for innovative solutions in a relatively short period of time [7]. The situation has forced the world to switch to new learning modalities including on-line pedagogy, virtual teaching and live broadcasts from the traditional in-person classroom learning. During the last few weeks, different stakeholders such as, governments, educational institutions, academicians, publishers, network operators, technology providers etc. have come closer to exploit on-line facilities instantly to handle this crisis. It seems that this emerging crisis will lead to more future possibilities and opportunities to use digital platforms for teaching/learning process along with the traditional ways of pedagogy.

\subsection{Research Questions}

This research project attempted to seek answers of the following research questions:

1. What online teaching practices help in enhancing students' understanding of the course content?

2. What online teaching practices help in increasing students' motivation level?

3. What online teaching practices help in fostering productive teacher-student rapport?

4. What online teaching practices help in ensuring students' active engagement in the learning process?

5. What online teaching practices help in maintaining extensive mutual interaction?

6. What are the skills needed by the teachers to deliver online course effectively?

7. What is the effectiveness of online teaching versus face to face teaching?

8. What differences exist in the perceptions of English language teachers from Saudi universities (Sus) and from other Gulf universities (OGUs)?

\subsection{Null Hypotheses}

$\mathrm{H}_{0} 1$ : There does not exist any statistically significant difference in the perceptions of English language teachers from SUs and from OGUs regarding the effectiveness of online teaching practices in enhancing students' understanding of the course content.

$\mathrm{H}_{0}$ 2: There does not exist any statistically significant difference in the perceptions of English language teachers from SUs and from OGUs regarding the effectiveness of online teaching practices in increasing students' motivation level.

$\mathrm{H}_{0} 3$ : There does not exist any statistically significant difference in the perceptions of English language teachers from SUs and from OGUs regarding the effectiveness of online teaching practices in maintaining extensive mutual interaction.

$\mathrm{H}_{0} 4$ : There does not exist any statistically significant difference in the perceptions of English language teachers from SUs and from OGUs regarding the effectiveness of online teaching practices in fostering productive teacher-student rapport.

$\mathrm{H}_{0} 5$ : There does not exist any statistically significant difference in the perceptions of English language teachers from SUs and from OGUs regarding the effectiveness of online teaching practices in ensuring active engagement of the students.

$\mathrm{H}_{0} 6$ : There does not exist any statistically significant difference in the perceptions of English language teachers from SUs and from OGUs regarding the skills needed for teachers to deliver online courses.

\section{Literature Review}

Basilaia \& Kvavadze [8] have reported that online 
pedagogy is a mode of learning "where the information technologies and communications are used to help in the development and acquisition of knowledge from the different remote locations. It uses the internet, video/audio and text communication and software to create the learning environment" (p. 1). They have further described that their other forms of online pedagogy include "knowledgebase, online support, asynchronous training, synchronous training, hybrid training" (p. 1). Among all these various modes, online pedagogy resembles to face to face teaching as both students and teachers log-in to the portal at a prescribed time and all participants can directly interact with each and engage in the learning process.

A growing mass of research has offered valuable insights into the fact that online pedagogy has been reported as effective as face to face teaching as far as its learning possibilities, cost-effectiveness, easy accessibility and broader scope are concerned $[9,10,11,12]$. Nguyen [12] has informed that online pedagogy has been found effective in enhancing "learning as measured by test scores, student engagement with the class material, improved perception of learning and of the online format, stronger sense of community among students, and reduction in withdrawal or failure" (P. 310). International Baccalaureate Organization [13] has enumerated blogging and vlogging; collaborative writing; discussion forums; E-portfolios; live audio/video chats; mind-mapping; multimedia presentations; video conferencing; virtual gallery walks; virtual reality scenarios; wiki building etc. as various learning strategies associated with online pedagogy. Zakaria, Awang, \& Abdul Rahman [14] have presented findings of host of studies which have investigated effectiveness of online pedagogy and reported that "online learning, traditional classrooms or both have significant effects on academic achievement are yet to be discovered" (p. 2419). This finding seems to encourage the experts in the field of online teaching to conduct investigations in various academic contexts to provide deeper insights related to this controversial area. Research has suggested that successful and active discussion among teachers and students significantly increase and promote online teaching effectiveness and has presented insightful recommendations related to best practices in this regard [15]. It has also been reported that best practices include providing academic support in the form of discussion forums, ensuring mutual respect among interlocuters during the process, targeting specific expectations, ensuring uninterrupted net connectivity, providing technical assistance to the faculty and students, motivating learners to instil variety to discussions, promoting cooperative activities and helping learners to link their acquisition to their lives [15].

Identification of the characteristics of effective online practices has been a concern of research and host of studies have been conducted worldwide in this regard. It has been reported that the following seven characteristics have been narrowed down and investigated by the researchers: 1). 'adapting strategies to student needs' $[16,17]$; 2) 'enhancing 3omprehension of the content through providing meaningful examples' [18]; 3) 'motivating students thorough various strategies to increase their participation and interest' [19]; 4) 'facilitating the students through effective course content presentation' [20]; 5) 'a systematic delivery of course content' $[21,22]$; 6) 'enhancing communication among the students and with the teacher' [23]; and 7) 'showing concern to ensure student learning' [16,19]. All these studies have thoroughly investigated various dimensions of online pedagogy and their role in achieving academic excellence and pedagogical effectiveness. A growing mass of research has revealed that along with face to face teaching, several effective online learning platforms have been widely used worldwide as well as in the Arab world. The findings of these studies have also reported positive and encouraging results in ensuring enhanced learning possibilities through effective use of learning platforms. It has been noticed that use of learning platforms has been effectively practiced in the advanced countries since the beginning of first decade of twenty-first century [24, 25, 26,27] and the trend has gained popularity in the Arab world starting at the end of the first decade of $21^{\text {st }}$ century as reported by host of studies [28, 29, 30,31,32]. A growing mass of research has also revealed that Saudi Arabia has also adopted this innovative mode of teaching to promote learning and ensure academic excellence especially in the context of higher studies at the end of first decade of $21^{\text {st }}$ century $[33,34,35,36,37,38,39,40]$.

\section{Materials and Methodology}

\subsection{Study Design and Methodology}

The present research project is based on quantitative paradigm as the researchers have administered a self-developed 5-point most effective to least effective scale questionnaire to collect data from the participants of this survey. The researchers have used survey research methodology to generate data which is suitable to the broader nature of this research study. Pinsonneault \& Kraemer [41] have defined 'survey' as a mean "for gathering information about the characteristics, actions, or opinions of a large group of people" (p. 77). Mathers, Fox, \& Hunn [42] have also reported that "a survey which is based on some form of random sampling technique will produce a sample which is representative of the particular population under study and will produce findings which may be generalized to the wider population" (p. 6). Considering the fact that this research study intends to involve a large population of faculty members from various universities situated in the kingdom of Saudi Arabia as well as in other Gulf countries, survey research seems most appropriate to address to this large population and its ability to produce reliable results and findings 
which will be generalized to the population as a whole. The survey has been administered to randomly selected participants to obtain useful and precise information on the specified issues related to the best practices in online pedagogy.

\subsection{Instrumentation}

The faculty survey instrument was a self-developed questionnaire to record perceptions of the participants of this survey related to various aspects of online pedagogy as detailed in research objectives and research questions on a 5-point scale of most effective to least effective. The final version of the instrument has the following eight sections:

1. Section 1: Demographic data of the participants

2. Section 2 (Items 1-8): Effectiveness of teaching strategies in enhancing students' understanding of the course content

3. Section 3 (Items 9-16): Effectiveness of teaching strategies in enhancing students' motivation level

4. Section 5 (Items 17-24): Effectiveness of teaching strategies in enhancing teacher-student rapport

5. Section 6 (Items 25-32): Effectiveness of teaching strategies in enhancing students' active engagement in the learning process

6. Section 4 (Items 33-40): Effectiveness of teaching strategies in maintaining extensive mutual interaction

7. Section 7 (Items 41-50): Importance of the skills needed for teachers to deliver online course successfully

8. Section 8 (Item 51): Effectiveness of online teaching versus face to face teaching on a scale of 1-10

\subsection{Reliability and Validity}

To determine the reliability and validity of the questionnaires, the researchers have developed a 51-item most effective to least effective Likert scale questionnaire to elicit data related to the objectives of this survey research. The final version of the questionnaire was sent to three experts in the field along with research topic, objectives questions with a request to review the instrument. The feedback of the experts received with no major observations. After determining its content validity, the instrument was piloted with 19 participants from Taif University. The responses generated were manually coded, entered and Cronbach alpha $(\alpha)$ reliability test was run to determine reliability of the instrument. Inter-item consistency of the final version of the questionnaire remained 0.972 for 51 indicators. Backhouse, Dickins, Rayner \& Wood [43] have reported that Cronbach $\alpha$ depended upon number of scales in the instrument, 0.972 is extremely high value of reliability. The final version of the questionnaire has been generalized to the participants of this survey research to generate data related to various aspects of effective teaching practices in online pedagogy to ascertain academic excellence in the context of higher education.

\subsection{The Participants}

The population of this survey study comprised of male and female faculty members serving in English departments of universities situated in various regions of Saudi Arabia and other Gulf countries who were engaged in online pedagogy during the suspension of face-to-face teaching because of corona pandemic. The participants of the study were randomly selected from SUs and OGUs. The participants of this comparative study included 94 (n =94) male and female faculty members from SUs situated in various regions of Saudi Arabia and $50(n=50)$ male and female faculty members from OGUs including UAE, Bahrain, Oman and Kuwait. To ensure maximum participation in the survey, the researchers have conveyed to the participants that their personal information would be kept secret and the demographic data would not be included in the analysis.

\subsection{Data Analysis}

The responses of the participants recorded through the questionnaire were manually coded, entered and independent samples $\mathrm{T}$-test was run to generate descriptive statistics in terms of means and standard deviations to measure their preferences as well as comparative statistics in terms of statistically significance differences in the perceptions of both groups with a level of significance for the t-test set at .05 to test six hypotheses set for this comparative survey study. The questionnaire items were placed on 5-point scale ranging from most effective to least effective where 5 stands for most effective and 1 for least effective. For the purpose of data analysis, higher mean values indicate the participants' higher preference whereas lower mean stands for perceived least effectiveness. The data have been presented in tabular form to facilitate understanding.

\section{Results and Discussion}

Independent samples T-test has been run to calculate descriptive analyses in terms of means and standard deviations of the questionnaire items as well as to identify whether any statistically significant difference existed in the perceptions of the participants of this survey research related to the effectiveness of various teaching strategies, importance of the skills needed for teachers to deliver online course successfully and the effectiveness of online teaching versus face-to-face teaching. The data generated have been presented in tabular form to present results, generate discussion and compare the findings to the published research. 
Table 1. Analyses for strategies of enhancing students' understanding

\begin{tabular}{|c|c|c|c|c|c|c|c|}
\hline \multicolumn{8}{|c|}{ Effectiveness of the following teaching strategies in enhancing students' understanding of the course content } \\
\hline \multicolumn{2}{|c|}{ Teaching strategies: } & \multirow{2}{*}{$\begin{array}{c}\text { Group } \\
\text { SUs }\end{array}$} & \multirow{2}{*}{$\frac{\mathrm{N}}{94}$} & \multirow{2}{*}{$\frac{\mathrm{M}}{3.4043}$} & \multirow{2}{*}{$\frac{\mathrm{df}}{142}$} & \multicolumn{2}{|c|}{$\mathrm{p}$ value } \\
\hline \multirow{2}{*}{1} & \multirow{2}{*}{ Lecturing } & & & & & .120 & \multirow{2}{*}{$\mathrm{p}>0.05$} \\
\hline & & OGUs & 50 & 3.7200 & 112.40 & .106 & \\
\hline \multirow{2}{*}{2} & \multirow{2}{*}{$\begin{array}{c}\text { Asking } \\
\text { comprehension } \\
\text { questions }\end{array}$} & SUs & 94 & 4.1702 & 142 & .212 & \multirow{2}{*}{$\mathrm{p}>0.05$} \\
\hline & & OGUs & 50 & 4.0000 & 103.38 & .207 & \\
\hline \multirow{2}{*}{3} & \multirow{2}{*}{$\begin{array}{l}\text { Teacher-student } \\
\text { interaction }\end{array}$} & SUs & 94 & 4.1702 & 142 & .041 & \multirow{2}{*}{$\mathrm{p}<0.05$} \\
\hline & & OGUs & 50 & 3.8000 & 82.451 & .058 & \\
\hline \multirow{2}{*}{4} & \multirow{2}{*}{ Written assignments } & SUs & 94 & 3.8511 & 142 & .063 & \multirow{2}{*}{$\mathrm{p}>0.05$} \\
\hline & & OGUs & 50 & 3.5200 & 96.641 & .067 & \\
\hline \multirow{2}{*}{5} & \multirow{2}{*}{ Group projects } & SUs & 94 & 3.6383 & 142 & .822 & \multirow{2}{*}{$\mathrm{p}>0.05$} \\
\hline & & OGUs & 50 & 3.6000 & 87.544 & .830 & \\
\hline \multirow{2}{*}{6} & \multirow{2}{*}{ Individual projects } & SUs & 94 & 3.7872 & 142 & .518 & \multirow{2}{*}{$\mathrm{p}>0.05$} \\
\hline & & OGUs & 50 & 3.6800 & 101.32 & .516 & \\
\hline \multirow{2}{*}{7} & \multirow{2}{*}{$\begin{array}{l}\text { Teachers' oral } \\
\text { feedback }\end{array}$} & SUs & 94 & 4.0426 & 142 & .175 & \multirow{2}{*}{$\mathrm{p}>0.05$} \\
\hline & & OGUs & 50 & 3.8400 & 94.147 & .186 & \\
\hline \multirow{2}{*}{8} & \multirow{2}{*}{$\begin{array}{l}\text { Teachers' written } \\
\text { feedback }\end{array}$} & SUs & 94 & 3.9787 & 142 & .698 & \multirow{2}{*}{$\mathrm{p}>0.05$} \\
\hline & & OGUs & 50 & 3.9200 & 101.49 & 697 & \\
\hline
\end{tabular}

Table 1 details the data generated for the items related to teaching strategies in enhancing students' understanding through independent-samples T-test and the participants have allocated medium high mean values to the majority of the questionnaire items of this category. The data have revealed that 'asking comprehension questions', teacher-student interaction' and 'teachers' oral feedback' respectively have been perceived the most effective teaching strategies in this regard. High mean values assigned to these three teaching strategies suggest that active interaction among teachers and students is instrumental in enhancing students' understating of teaching material. Previous research also confirms this finding as Frazer, Sullivan, Weatherspoon and Hussey [44] have reported that participants of their study "viewed the interaction that takes place in the online learning environment as the essence of teaching effectiveness and quality indicators that enhance positive outcomes" (p. 5).

'Writing assignments' and 'lecturing' have been declared the least effective teaching strategies in enhancing students' understanding of the teaching content as perceived by the participants of this survey research. Another interesting finding is that the participants from SUs have assigned higher mean values than the participants from OGUs in all items of this category other than 'lecturing'. The only item which showed statistically significant difference remained 'teacher-student interaction' as perceived by the participants of the study. 

during Corona Pandemic in Ensuring Sustainable Pedagogy

Table 2. Analyses for strategies of enhancing students' motivation level

\begin{tabular}{|c|c|c|c|c|c|c|c|}
\hline \multicolumn{8}{|c|}{ Effectiveness of the following teaching strategies in enhancing students' motivation level } \\
\hline \multicolumn{2}{|c|}{ Teaching strategies: } & \multirow{2}{*}{$\begin{array}{c}\text { Group } \\
\text { SUs }\end{array}$} & \multirow{2}{*}{$\begin{array}{l}\mathrm{N} \\
94\end{array}$} & \multirow{2}{*}{$\begin{array}{c}\mathrm{M} \\
3.234\end{array}$} & \multirow{2}{*}{$\frac{\mathrm{df}}{142}$} & \multicolumn{2}{|c|}{$\mathrm{p}$ value } \\
\hline \multirow{2}{*}{9} & \multirow{2}{*}{ Lecturing } & & & & & .069 & \multirow{2}{*}{$\mathrm{p}>0.05$} \\
\hline & & OGUs & 50 & 3.600 & 113.60 & .058 & \\
\hline \multirow{2}{*}{10} & \multirow{2}{*}{$\begin{array}{l}\text { Asking comprehension } \\
\text { questions }\end{array}$} & SUs & 94 & 3.766 & 142 & .420 & \multirow{2}{*}{$\mathrm{p}>0.05$} \\
\hline & & OGUs & 50 & 3.640 & 113.78 & .399 & \\
\hline \multirow{2}{*}{11} & \multirow{2}{*}{$\begin{array}{l}\text { Teacher-student } \\
\text { interaction }\end{array}$} & SUs & 94 & 4.276 & 142 & .018 & \multirow{2}{*}{$\mathrm{p}<0.05$} \\
\hline & & OGUs & 50 & 3.920 & 81.216 & .029 & \\
\hline \multirow{2}{*}{12} & \multirow{2}{*}{ Written assignments } & SUs & 94 & 3.574 & 142 & .348 & \multirow{2}{*}{$\mathrm{p}>0.05$} \\
\hline & & OGUs & 50 & 3.4000 & 94.175 & .359 & \\
\hline \multirow{2}{*}{13} & \multirow{2}{*}{ Group projects } & SUs & 94 & 3.7660 & 142 & .131 & \multirow{2}{*}{$\mathrm{p}>0.05$} \\
\hline & & OGUs & 50 & 3.5200 & 102.31 & .129 & \\
\hline \multirow{2}{*}{14} & \multirow{2}{*}{ Individual projects } & SUs & 94 & 3.8298 & 142 & .668 & \multirow{2}{*}{$\mathrm{p}>0.05$} \\
\hline & & OGUs & 50 & 3.7600 & 90.227 & .680 & \\
\hline \multirow{2}{*}{15} & \multirow{2}{*}{ Teachers' oral feedback } & SUs & 94 & 4.0638 & 142 & .001 & \multirow{2}{*}{$\mathrm{p}<0.05$} \\
\hline & & OGUs & 50 & 3.5600 & 100.50 & .001 & \\
\hline \multirow{2}{*}{16} & \multirow{2}{*}{$\begin{array}{l}\text { Teachers' written } \\
\text { feedback }\end{array}$} & SUs & 94 & 3.9362 & 142 & .273 & \multirow{2}{*}{$\mathrm{p}>0.05$} \\
\hline & & OGUs & 50 & 3.7600 & 83.525 & .305 & \\
\hline
\end{tabular}

The data presented in table 2 have revealed that the participants assigned medium high mean values of lower than 4 to all teaching strategies in enhancing students' motivation level except items 11 and 15 namely 'teacher-student interaction' and 'teachers' oral feedback' which received high mean values of 4.276 and 4.0638 for both these items respectively by the participants from SUs. The data analyses also show that these two items have been indicated as most effective to raise students' motivation level. The results are in line with the findings of table 1 which also exhibit that teacher-student interaction and teachers' oral feedback are among the most preferred teaching strategies in enhancing content understanding as well. This finding strongly suggests that for effectively enhancing students' motivation level, the faculty members have to ensure maximum mutual interaction. The results are in line of the findings presented by Bao [45] who have stated that teachers' efficient support in terms of timely feedback and encouraging students to actively participate in classroom proceeding enhance students' motivation.

The least preferred items remained 'lecturing' and 'written assignment' in enhancing in motivation level of the students as reported by both groups of the participants. This also highlights the same trends of least significance of teaching strategies which do not include active interaction between teachers and students. The results of this set of questionnaire items are also in line with the trend witnessed in table 1 in which the participants from SUs have assigned higher mean values to all items except 'lecturing'. The comparative analyses have indicated statistically significant difference in the perceptions of both groups in only two items which are 'teacher-student interaction' and 'teachers' oral feedback'. 
Table 3. Analyses for strategies of enhancing teacher-student rapport

\begin{tabular}{|c|c|c|c|c|c|c|c|}
\hline \multicolumn{8}{|c|}{ Effectiveness of the following teaching strategies in enhancing teacher-student rapport } \\
\hline \multicolumn{2}{|c|}{ Teaching strategies: } & \multirow{2}{*}{$\begin{array}{c}\text { Group } \\
\text { SUs }\end{array}$} & \multirow{2}{*}{$\begin{array}{l}\mathrm{N} \\
94\end{array}$} & \multirow{2}{*}{$\frac{\mathrm{M}}{3.212}$} & \multirow{2}{*}{$\frac{\mathrm{df}}{142}$} & \multicolumn{2}{|c|}{$\mathrm{p}$ value } \\
\hline \multirow{2}{*}{17} & \multirow{2}{*}{ Lecturing } & & & & & .605 & \multirow{2}{*}{$\mathrm{p}>0.05$} \\
\hline & & OGUs & 50 & 3.320 & 105.8 & .598 & \\
\hline \multirow{2}{*}{18} & \multirow{2}{*}{$\begin{array}{l}\text { Asking comprehension } \\
\text { questions }\end{array}$} & SUs & 94 & 3.893 & 142 & .076 & \multirow{2}{*}{$\mathrm{p}>0.05$} \\
\hline & & OGUs & 50 & 3.600 & 98.72 & .078 & \\
\hline \multirow{2}{*}{19} & \multirow{2}{*}{$\begin{array}{l}\text { Teacher-student } \\
\text { interaction }\end{array}$} & SUs & 94 & 4.276 & 142 & .079 & \multirow{2}{*}{$\mathrm{p}>0.05$} \\
\hline & & OGUs & 50 & 3.960 & 101.9 & .078 & \\
\hline \multirow{2}{*}{20} & \multirow{2}{*}{ Written assignments } & SUs & 94 & 3.361 & 142 & .416 & \multirow{2}{*}{$\mathrm{p}>0.05$} \\
\hline & & OGUs & 50 & 3.520 & 99.66 & .417 & \\
\hline \multirow{2}{*}{21} & \multirow{2}{*}{ Group projects } & SUs & 94 & 3.489 & 142 & .491 & \multirow{2}{*}{$\mathrm{p}>0.05$} \\
\hline & & OGUs & 50 & 3.360 & 92.10 & .505 & \\
\hline \multirow{2}{*}{22} & \multirow{2}{*}{ Individual projects } & SUs & 94 & 3.702 & 142 & .114 & \multirow{2}{*}{$\mathrm{p}>0.05$} \\
\hline & & OGUs & 50 & 3.960 & 88.78 & .131 & \\
\hline \multirow{2}{*}{23} & \multirow{2}{*}{ Teachers' oral feedback } & SUs & 94 & 4.127 & 142 & .144 & \multirow{2}{*}{$\mathrm{p}>0.05$} \\
\hline & & OGUs & 50 & 3.880 & 100.3 & .145 & \\
\hline \multirow{2}{*}{24} & \multirow{2}{*}{$\begin{array}{l}\text { Teachers' written } \\
\text { feedback }\end{array}$} & SUs & 94 & 3.808 & 142 & .386 & \multirow{2}{*}{$\mathrm{p}>0.05$} \\
\hline & & OGUs & 50 & 3.960 & 98.12 & .390 & \\
\hline
\end{tabular}

Table 3 contains the data generated through comparative analyses of the role of teaching strategies in enhancing teacher-student rapport. The data have revealed that the participants from SUs recorded higher preferences to three items which involve active interaction among the teachers and students, i.e., items 18, 19 and 23, as compared to their counterparts from OGUs whereas the participants from OGUs have assigned higher mean to other 5 items. Collective mean indicates that both groups have perceived 'teacher-student interaction' and 'teachers' oral feedback' as the most effective in increasing teacher-student interaction. The finding is in accordance with the data related to teaching strategies as presented in tables 1 and 2 which have also reported these two items as instrumental in enhancing content understanding and students' motivation as well. Both groups have seen eye to eye with each other in perceiving limited effectiveness of 'lecturing', 'written assignments' and 'group projects' as indicated by the least mean value assigned to these items. Another important finding is that there is no statistically significant difference in the perceptions of both groups in any teaching strategy. 

during Corona Pandemic in Ensuring Sustainable Pedagogy

Table 4. Analyses for strategies of enhancing students' active engagement in the learning process

\begin{tabular}{|c|c|c|c|c|c|c|c|}
\hline \multicolumn{8}{|c|}{ Effectiveness of the following teaching strategies in enhancing students' active engagement in the learning process } \\
\hline \multicolumn{2}{|r|}{ Teaching strategies: } & \multirow{2}{*}{$\frac{\text { Group }}{\text { SUs }}$} & \multirow{2}{*}{$\frac{\mathrm{N}}{94}$} & \multirow{2}{*}{$\begin{array}{c}\mathrm{M} \\
2.9574\end{array}$} & \multirow{2}{*}{$\begin{array}{c}\mathrm{df} \\
142\end{array}$} & \multicolumn{2}{|c|}{$\mathrm{p}$ value } \\
\hline \multirow{2}{*}{25} & \multirow{2}{*}{ Lecturing } & & & & & .412 & \multirow{2}{*}{$\mathrm{p}>0.05$} \\
\hline & & OGUs & 50 & 3.1200 & 110.68 & .396 & \\
\hline \multirow{2}{*}{26} & \multirow{2}{*}{$\begin{array}{l}\text { Asking comprehension } \\
\text { questions }\end{array}$} & SUs & 94 & 4.0426 & 142 & .008 & \multirow{2}{*}{$\mathrm{p}>0.05$} \\
\hline & & OGUs & 50 & 3.6000 & 87.382 & .012 & \\
\hline \multirow{2}{*}{27} & \multirow{2}{*}{ Teacher-student interaction } & SUs & 94 & 4.2128 & 142 & .038 & \multirow{2}{*}{$\mathrm{p}<0.05$} \\
\hline & & OGUs & 50 & 3.8800 & 78.308 & .059 & \\
\hline \multirow{2}{*}{28} & \multirow{2}{*}{ Written assignments } & SUs & 94 & 3.5106 & 142 & .960 & \multirow{2}{*}{$\mathrm{p}>0.05$} \\
\hline & & OGUs & 50 & 3.5200 & 108.72 & .959 & \\
\hline \multirow{2}{*}{29} & \multirow{2}{*}{ Group projects } & SUs & 94 & 3.7234 & 142 & .340 & \multirow{2}{*}{$\mathrm{p}>0.05$} \\
\hline & & OGUs & 50 & 3.5600 & 97.713 & .345 & \\
\hline \multirow{2}{*}{30} & \multirow{2}{*}{ Individual projects } & SUs & 94 & 3.8298 & 142 & .164 & \multirow{2}{*}{$\mathrm{p}>0.05$} \\
\hline & & OGUs & 50 & 3.6000 & 98.900 & .167 & \\
\hline \multirow{2}{*}{31} & \multirow{2}{*}{ Teachers' oral feedback } & SUs & 94 & 3.9574 & 142 & .070 & \multirow{2}{*}{$\mathrm{p}>0.05$} \\
\hline & & OGUs & 50 & 3.6800 & 103.68 & .067 & \\
\hline \multirow{2}{*}{32} & \multirow{2}{*}{ Teachers' written feedback } & SUs & 94 & 3.5319 & 142 & .727 & \multirow{2}{*}{$\mathrm{p}>0.05$} \\
\hline & & OGUs & 50 & 3.6000 & 105.25 & .722 & \\
\hline
\end{tabular}

Table 4 presents data generated through comparative analyses of items related to effectiveness of teaching strategies in enhancing students' active engagement in the learning process and the participants have assigned medium high mean values of less than 4 to all items except 'teacher-students interaction' and 'asking comprehension questions' which were assigned high mean values of 4.21 and 4.04 respectively by the participants from SUs. The participants from OGUs have allocated medium high values to these items as well. These two items also received highest collective mean by both groups reflecting their perception that these are the most effective teaching strategies to ensure students' active engagement in the learning process. 'Teachers' oral feedback' remained $3^{\text {rd }}$ in the rank of preference in this regard confirming the trend of effectiveness of these three highly preferred items in tables 1, 2 and 3 as well.
The finding is in line with the study of Lervik, Vold, \& Holen [46] who have reported that "a high level of involvement and engagement will increase the learning outcome from the subsequent online teaching" (p. 2352).

In line with the general trend in the previous sections, the participants have perceived 'lecturing' and 'written assignments' as the least effective teaching strategies to enhance students' active engagement in the learning process emphasizing the pedagogical need to incorporating maximum chances of mutual interaction for successful online pedagogy. Items 25,29 and 32 have been assigned comparatively higher mean values by the participants form OGUs whereas the other 5 items have been allocated higher preference by the participants from SUs. Results of independent-samples t-test have recorded statistically significant difference in only one item which is 'teacher-student interaction'. 
Table 5. Analyses for strategies of maintaining extensive mutual interaction

\begin{tabular}{|c|c|c|c|c|c|c|c|}
\hline \multicolumn{8}{|c|}{ Effectiveness of the following teaching strategies in maintaining extensive mutual interaction } \\
\hline \multicolumn{2}{|c|}{ Teaching strategies: } & \multirow{2}{*}{$\begin{array}{c}\text { Group } \\
\text { SUs }\end{array}$} & \multirow{2}{*}{$\frac{N}{94}$} & \multirow{2}{*}{$\begin{array}{c}\mathrm{M} \\
3.106\end{array}$} & \multirow{2}{*}{$\frac{\mathrm{df}}{142}$} & \multicolumn{2}{|c|}{$\mathrm{p}$ value } \\
\hline \multirow{2}{*}{33} & \multirow{2}{*}{ Lecturing } & & & & & .373 & \multirow{2}{*}{$\mathrm{p}>0.05$} \\
\hline & & OGUs & 50 & 3.280 & 128.6 & .328 & \\
\hline \multirow{2}{*}{34} & \multirow{2}{*}{$\begin{array}{l}\text { Asking comprehension } \\
\text { questions }\end{array}$} & SUs & 94 & 3.978 & 142 & .295 & \multirow{2}{*}{$\mathrm{p}>0.05$} \\
\hline & & OGUs & 50 & 3.800 & 109.7 & .280 & \\
\hline \multirow{2}{*}{35} & \multirow{2}{*}{$\begin{array}{l}\text { Teacher-student } \\
\text { interaction }\end{array}$} & SUs & 94 & 4.2979 & 142 & .177 & \multirow{2}{*}{$\mathrm{p}>0.05$} \\
\hline & & OGUs & 50 & 4.0800 & 102.54 & .174 & \\
\hline \multirow{2}{*}{36} & \multirow{2}{*}{ Written assignments } & SUs & 94 & 3.3404 & 142 & .253 & \multirow{2}{*}{$\mathrm{p}>0.05$} \\
\hline & & OGUs & 50 & 3.5600 & 123.85 & .216 & \\
\hline \multirow{2}{*}{37} & \multirow{2}{*}{ Group projects } & SUs & 94 & 3.9149 & 142 & .245 & \multirow{2}{*}{$\mathrm{p}>0.05$} \\
\hline & & OGUs & 50 & 3.7200 & 104.02 & .240 & \\
\hline \multirow{2}{*}{38} & \multirow{2}{*}{ Individual projects } & SUs & 94 & 3.5106 & 142 & .299 & \multirow{2}{*}{$\mathrm{p}>0.05$} \\
\hline & & OGUs & 50 & 3.6800 & 93.204 & .312 & \\
\hline \multirow{2}{*}{39} & \multirow{2}{*}{$\begin{array}{l}\text { Teachers' oral } \\
\text { feedback }\end{array}$} & SUs & 94 & 3.8936 & 142 & .118 & \multirow{2}{*}{$\mathrm{p}>0.05$} \\
\hline & & OGUs & 50 & 3.6400 & 103.43 & .115 & \\
\hline \multirow{2}{*}{40} & \multirow{2}{*}{$\begin{array}{l}\text { Teachers' written } \\
\text { feedback }\end{array}$} & SUs & 94 & 3.4681 & 142 & .349 & \multirow{2}{*}{$\mathrm{p}>0.05$} \\
\hline & & OGUs & 50 & 3.6400 & 119.75 & .318 & \\
\hline
\end{tabular}

Table 5 contains the data generated through comparative analyses of the teaching strategies effectiveness in maintaining mutual interaction and the participants have allotted medium high values to all items except 'teacher-student interaction' which gained high preference by both groups indicating its role in extensive mutual interaction. The remaining highly preferred items have been 'asking comprehension questions' and 'group projects' respectively. The finding seems to suggest that teachers' comprehension questions and completion of group projects generate extensive mutual interaction among the teachers and students. Same findings have been reported by Frazer, Sullivan, Weatherspoon, \& Hussey [44] that teaching strategies such as "sharing experiences, communicating through announcements, phone calls, and emails, answering questions, providing detailed feedback, and asking probing/prompting questions in the discussion forums lead themselves not only to building that feeling of connection in an online environment but towards student reflection and construction of meaning" (p. 5).

In line with previous findings as presented in tables 1, 2,3 and 4, the participants have also reported 'lecturing' and 'written assignments' as the least effective in maintaining extensive mutual interaction. The comparative analyses have reported that both groups did not bear any statistically significant differences in their perceptions related to the role of these teaching strategies in maintaining extensive interaction between teachers and students. Another finding is that both groups have allocated higher values as compared to the other one in four items. 

during Corona Pandemic in Ensuring Sustainable Pedagogy

Table 6. Analyses for skills to deliver online course successfully

\begin{tabular}{|c|c|c|c|c|c|c|c|}
\hline \multicolumn{8}{|c|}{ Importance of the skills needed for teachers to deliver online course successfully } \\
\hline \multicolumn{2}{|r|}{ Skills: } & \multirow{2}{*}{$\begin{array}{c}\text { Group } \\
\text { SUs }\end{array}$} & \multirow{2}{*}{$\begin{array}{l}\mathrm{N} \\
94\end{array}$} & \multirow{2}{*}{$\frac{M}{4.6170}$} & \multirow{2}{*}{$\frac{\mathrm{df}}{142}$} & \multicolumn{2}{|c|}{$\mathrm{p}$ value } \\
\hline \multirow{2}{*}{41} & \multirow{2}{*}{ Communication skills } & & & & & .019 & \multirow{2}{*}{$\mathrm{p}<0.05$} \\
\hline & & OGUs & 50 & 4.3200 & 87.00 & .027 & \\
\hline \multirow{2}{*}{42} & \multirow{2}{*}{$\begin{array}{l}\text { Compassion and } \\
\text { empathy }\end{array}$} & SUs & 94 & 4.4468 & 142 & .002 & \multirow{2}{*}{$\mathrm{p}<0.05$} \\
\hline & & OGUs & 50 & 3.9600 & 68.66 & .007 & \\
\hline \multirow{2}{*}{43} & \multirow{2}{*}{ Patience } & SUs & 94 & 4.6383 & 142 & .000 & \multirow{2}{*}{$\mathrm{p}<0.05$} \\
\hline & & OGUs & 50 & 4.2400 & 84.38 & .000 & \\
\hline \multirow{2}{*}{44} & \multirow{2}{*}{ Subject expertise } & SUs & 94 & 4.5745 & 142 & .024 & \multirow{2}{*}{$\mathrm{p}<0.05$} \\
\hline & & OGUs & 50 & 4.3200 & 81.29 & .038 & \\
\hline \multirow{2}{*}{45} & \multirow{2}{*}{ Time management } & SUs & 94 & 4.5957 & 142 & .011 & \multirow{2}{*}{$\mathrm{p}<0.05$} \\
\hline & & OGUs & 50 & 4.3200 & 98.60 & .012 & \\
\hline \multirow{2}{*}{46} & \multirow{2}{*}{$\begin{array}{l}\text { Monitoring students' } \\
\text { learning }\end{array}$} & SUs & 94 & 4.2340 & 142 & .141 & \multirow{2}{*}{$\mathrm{p}>0.05$} \\
\hline & & OGUs & 50 & 3.9600 & 117.6 & .119 & \\
\hline \multirow{2}{*}{47} & \multirow{2}{*}{$\begin{array}{c}\text { Provision of } \\
\text { informative feedback }\end{array}$} & SUs & 94 & 4.3617 & 142 & .100 & \multirow{2}{*}{$\mathrm{p}>0.05$} \\
\hline & & OGUs & 50 & 4.1200 & 110.3 & .090 & \\
\hline \multirow{2}{*}{48} & \multirow{2}{*}{$\begin{array}{l}\text { Assessment and } \\
\text { evaluative skills }\end{array}$} & SUs & 94 & 4.2766 & 142 & .382 & \multirow{2}{*}{$\mathrm{p}>0.05$} \\
\hline & & OGUs & 50 & 4.1200 & 137.6 & .280 & \\
\hline \multirow{2}{*}{49} & \multirow{2}{*}{$\begin{array}{l}\text { Providing student } \\
\text { support }\end{array}$} & SUs & 94 & 4.5106 & 142 & .025 & \multirow{2}{*}{$\mathrm{p}<0.05$} \\
\hline & & OGUs & 50 & 4.2000 & 126.0 & .015 & \\
\hline
\end{tabular}

Table 6 presents data related to the role of 9 important skills in delivering online courses successfully. The participants from KSAUs have allocated extremely high preference as indicated by high mean values of 4.23 and above for all these 9 skills. The participants from OGUs have also assigned high mean values and there was only one item which was allocated less than 4. Comparative mean has suggested that all the participants of this survey research consider 'communication skills' as the most important skill to cope up with online teaching followed by 'patience' and 'time management' respectively. The most favored skills seem equally important in online teaching situations and the faculty need to have excellent communication skills and time management to cope up with online pedagogy. Academic skills of 'compassion and empathy' and 'monitoring students' learning' have been allocated the lowest mean of 3.96 by the participants from OGUs whereas the participants from SUs have allotted higher values of 4.234 and 4.446 respectively to both these items. Another interesting finding is that all 9 academic skills have been assigned higher values by the participants from SUs as compared to the participants from OGUs. Comparative analyses generated by independent samples T-test have recorded statistically significant difference in the perception of both groups in 7 items as mentioned in table 6 . 
Table 7. Analyses for rate of effectiveness of online teaching

\begin{tabular}{|c|c|c|c|c|c|c|c|}
\hline \multicolumn{8}{|c|}{ How do you rate the effectiveness of online teaching versus face to face teaching on the following scale? } \\
\hline \multirow{2}{*}{50} & Group & N & M & df & \multicolumn{2}{|c|}{$\mathrm{p}$ value } \\
\hline \multirow{2}{*}{50} & \multirow{2}{*}{ Rating of effectiveness } & SUs & 94 & 5.7957 & 141 & .829 & $\mathrm{p}>0.05$ \\
\cline { 3 - 8 } & & OGUs & 50 & 5.7200 & 90.719 & .835 & \\
\hline
\end{tabular}

Table 7 contains data analyses of one concluding item related to the effectiveness of online teaching versus face-to-face teaching on 10-point scale and both groups have assigned medium mean values of 5.7957 and 5.72 respectively by the participants from SUs and OGUs indicating that the participants believe that online teaching is reasonably less effective as compared to face-to-face teaching. This finding confirms the findings of previous research studies which have reported that faculty members did not prefer online teaching to face-to-face teaching [47, $48,49,50]$.

\section{Findings and Recommendations}

The participants of the study have seen eye to eye with each other in majority of the questionnaire items and ranked 'asking comprehension questions', teacher-student interaction' and 'teachers' oral feedback' as the most preferred teaching strategies in enhancing content understanding, students' motivation, mutual interaction, teacher-student rapport and active engagement in learning. This important finding brings prominence to the role of these pedagogical strategies in ensuring enhanced active cooperation of learners and faculty members in learning process in promoting various pedagogical paradigms ranging from teaching material comprehension, motivation level and rapport and enhancing learning possibilities. This significant finding seems to suggest that the faculty members should exploit these pedagogical strategies more in online pedagogy so that strong academic bond is established among the learners and faculty members to ensure productive interaction during online pedagogy which results in increased interest, active participation, enhanced motivation and better comprehension among their students. The findings of the study also suggest that mere lecturing, written assignments, individual projects have been identified least effective in online pedagogy. Therefore, it is highly recommended that these teaching strategies should be exercised the least so that a productive learning atmosphere is maintained during online pedagogy.

Among the most important pedagogical skills needed to deliver successful online courses, 'communication skills' and 'patience' have been perceived most effective. This finding strongly suggests that it is not possible to carry out effective online teaching without effective communication skills and patience. After these two most favored items, 'subject expertise' and 'time management' have been ranked the next most important skills for successful online teaching. It is highly recommended that, to carry out successful online pedagogy, the faculty members need their professional skills. Therefore, it seems unavoidable to keep themselves abreast with latest advancement in their relevant fields so that they may be able to satisfy their students' inquisitiveness. The changing paradigm of pedagogy also requires the faculty members to enhance their time management skills which are needed at much higher level in online pedagogy as compared to face-to-face teaching. It is also necessary that faculty members should exercise patience during their online teaching sessions as online pedagogy poses more challenges for the teachers to handle as compared to face-to-face teaching. Furthermore, the remaining skills have also been assigned high mean values indicating their significance in online pedagogy.

Questionnaire items 1-40 are meant to elicit the perceptions of faculty members from SUs and from OGUs regarding the effectiveness of online teaching practices and comparative analyses indicate a statistically significant difference in only 4 items; therefore, accepting null hypotheses 1-5 set for this survey. Hypothesis 6 was meant to identify whether any statistically significant difference existed in the perceptions of faculty members from SUs and from OGUs regarding the skills needed to deliver online courses. The result rejected null hypothesis 6 as 7 items out of 10 items showed significant differences.

\section{Acknowledgements}

The study was funded by the Deanship of Scientific Research, Taif University, KSA [Research project number 1-441-38]. 


\section{Appendix \# 1 - Reliability Statistics}

\section{Case Processing Summary}

\begin{tabular}{|c|c|c|c|}
\hline \multicolumn{2}{|c|}{} & $\mathrm{N}$ & $\%$ \\
\hline \multirow{3}{*}{ Cases } & Valid & 19 & 100.0 \\
\cline { 2 - 4 } & Excluded $^{\mathrm{a}}$ & 0 & .0 \\
\cline { 2 - 4 } & Total & 19 & 100.0 \\
\hline \multicolumn{2}{|c|}{ a. Listwise deletion based on all variables in the procedure. } \\
\hline
\end{tabular}

\begin{tabular}{|c|c|}
\hline \multicolumn{2}{|c|}{ Reliability Statistics } \\
\hline Cronbach's Alpha & N of Items \\
\hline .972 & 51 \\
\hline \multicolumn{2}{|c|}{ Item-Total Statistics } \\
\hline
\end{tabular}

\begin{tabular}{|c|c|c|c|c|}
\hline & Scale Mean if Item Deleted & $\begin{array}{c}\text { Scale Variance if Item } \\
\text { Deleted }\end{array}$ & $\begin{array}{l}\text { Corrected Item-Total } \\
\text { Correlation }\end{array}$ & $\begin{array}{c}\text { Cronbach's Alpha if Item } \\
\text { Deleted }\end{array}$ \\
\hline VAR00001 & 213.2632 & 725.871 & .738 & .971 \\
\hline VAR00002 & 213.0000 & 752.111 & .411 & .972 \\
\hline VAR00003 & 213.0000 & 740.333 & .603 & .971 \\
\hline VAR00004 & 213.3684 & 736.912 & .585 & .971 \\
\hline VAR00005 & 213.7368 & 749.649 & .339 & .972 \\
\hline VAR00006 & 213.4211 & 736.480 & .478 & .972 \\
\hline VAR00007 & 213.2105 & 735.398 & .746 & .971 \\
\hline VAR00008 & 213.3158 & 750.895 & .342 & .972 \\
\hline VAR00009 & 213.6316 & 725.357 & .745 & .971 \\
\hline VAR00010 & 213.2632 & 737.649 & .794 & .971 \\
\hline VAR00011 & 213.1053 & 737.877 & .742 & .971 \\
\hline VAR00012 & 213.6842 & 731.673 & .751 & .971 \\
\hline VAR00013 & 213.6316 & 745.357 & .421 & .972 \\
\hline VAR00014 & 213.4211 & 737.702 & .699 & .971 \\
\hline VAR00015 & 213.1579 & 743.474 & .598 & .971 \\
\hline VAR00016 & 213.2632 & 747.760 & .448 & .972 \\
\hline VAR00017 & 213.5789 & 725.702 & .758 & .971 \\
\hline VAR00018 & 213.2632 & 740.427 & .715 & .971 \\
\hline VAR00019 & 212.8947 & 745.433 & .628 & .971 \\
\hline VAR00020 & 213.8947 & 717.322 & .838 & .970 \\
\hline VAR00021 & 213.8947 & 740.544 & .554 & .971 \\
\hline VAR00022 & 213.5263 & 741.819 & .588 & .971 \\
\hline VAR00023 & 213.2632 & 729.094 & .720 & .971 \\
\hline VAR00024 & 213.4737 & 735.819 & .705 & .971 \\
\hline VAR00025 & 214.0000 & 720.333 & .708 & .971 \\
\hline VAR00026 & 213.3684 & 730.135 & .728 & .971 \\
\hline VAR00027 & 213.2105 & 729.287 & .820 & .971 \\
\hline VAR00028 & 213.6316 & 728.579 & .848 & .970 \\
\hline VAR00029 & 213.6316 & 737.023 & .599 & .971 \\
\hline VAR00030 & 213.4211 & 729.257 & .767 & .971 \\
\hline VAR00031 & 213.4737 & 723.485 & .856 & .970 \\
\hline VAR00032 & 213.6316 & 739.023 & .604 & .971 \\
\hline
\end{tabular}


Appendix \# 1 Continued

\begin{tabular}{|c|l|l|l|l|}
\hline VAR00033 & 213.7895 & 720.175 & .848 & .970 \\
\hline VAR00034 & 213.3158 & 719.784 & .743 & .971 \\
\hline VAR00035 & 213.0526 & 728.608 & .814 & .971 \\
\hline VAR00036 & 213.8421 & 716.918 & .852 & .971 \\
\hline VAR00037 & 213.4211 & 731.368 & .631 & .971 \\
\hline VAR00038 & 213.6316 & 729.801 & .819 & .970 \\
\hline VAR00039 & 213.3158 & 724.561 & .890 & .970 \\
\hline VAR00040 & 213.7368 & 714.871 & .866 & .971 \\
\hline VAR00041 & 212.7895 & 743.953 & .717 & .971 \\
\hline VAR00042 & 212.9474 & 748.497 & .524 & .971 \\
\hline VAR00043 & 212.7895 & 750.509 & .627 & .972 \\
\hline VAR00044 & 212.6842 & 762.450 & .178 & .971 \\
\hline VAR00045 & 212.6842 & 753.450 & .616 & .972 \\
\hline VAR00046 & 212.7368 & 758.538 & .327 & .971 \\
\hline VAR00047 & 212.8421 & 749.251 & .523 & .671 \\
\hline VAR00048 & 212.6842 & 751.784 & .638 & .140 \\
\hline VAR00049 & 212.8421 & 732.696 & .307 & .971 \\
\hline VAR00050 & 212.6842 & 763.228 & 734.988 & .974 \\
\hline VAR00051 & 210.8947 & & & \\
\hline
\end{tabular}

\section{REFERENCES}

[1] Cucinotta D, M. Vanelli, "WHO declares COVID-19 a pandemic," Acta Bio-Medica: Atenei Parmensis, Vol. 91, no. 1, pp. 157-160, 2020.

[2] Mailizar, Almanthari A, Maulina S, S. Bruce, "Secondary school mathematics teachers' views on e-learning implementation barriers during the Covid-19 pandemic: The case of Indonesia," Eurasia Journal of Mathematics, Science and Technology Education, Vol. 16, no. 7, em1860, 2020.

[3] Toquero C. M, "Challenges and opportunities for higher education amid the COVID-19 pandemic: The Philippine context," Pedagogical Research, Vol. 5, no. 4, em0063, 2020. https://doi.org/10.29333/pr/7947

[4] Basilaia G, D. Kvavadze, "Transition to Online Education in Schools during a SARS-CoV-2 Coronavirus (COVID-19) Pandemic in Georgia," Pedagogical Research, Vol. 5, no. 4, em0060, 2020. https://doi.org/10.29333/pr/7937

[5] Middle East News, "Saudi Closes Schools, Universities because of Corona Virus," March 9, 2020. https://www.middleeastmonitor.com/20200309-saudi-close s-schools-universities-because-of-coronavirus/ (Accessed Jun. 4, 2020).

[6] UNESCO, "COVID-19 Educational Disruption and Response," March 4, 2020. Available online https://en.unesco.org/covid19/educationresponse (Assessed Jun13, 2020).

[7] Tam G, D. Al-Azer, "Three ways the coronavirus pandemic could reshape education, world economic forum," 2020 https://www.weforum.org/agenda/2020/03/3-ways-coronavi rus-is-reshaping-education-and-what-changes-might-be-her e-to-stay/ (Assessed July 8, 2020).

[8] Basilaia, G, D. Kvavadze, "Transition to Online Education in Schools during a SARS-CoV-2 Coronavirus (COVID-19) Pandemic in Georgia," Pedagogical Research, Vol. 5, no. 4, em0060, 2020. https://doi.org/10.29333/pr/7937

[9] Gratton-Lavoie C, D. Stanley, "Teaching and learning principles of Microeconomics online: An empirical assessment," The Journal of Economic Education, vol. 40, no. 1, pp. 3-25, 2009.

[10] De la Varre C, Keane J, M. J. Irvin, "Enhancing Online Distance Education in Small Rural US Schools: A Hybrid, Learner-Centred Model," Journal of Asynchronous Learning Networks, vol. 15, no. 4, pp. 35-46, 2011.

[11] Lorenzetti, J "Academic Administration - Running a MOOC: Secrets of the World's Largest Distance Education Classes" Magna Publications, 2013.

[12] Nguyen, $T$ "The Effectiveness of Online Learning: Beyond No Significant Difference and Future Horizons," MERLOT Journal of Online Learning and Teaching, vol. 11, no. 2, pp. 309-319, 2015.

[13] International Baccalaureate Organization, "Online learning, teaching and education continuity planning for schools. Peterson House," Malthouse Avenue, Cardiff Gate. Wales CF23 8GL, United Kingdom, 2020. Available online www.ibo.org.

[14] Zakaria M, Awang S, R Abdul Rahman, "Are MOOCs in Blended Learning More Effective than Traditional Classrooms for Undergraduate Learners?," Universal 
Journal of Educational Research, Vol. 7, No. 11, pp. 2417 2424, 2019. DOI: 10.13189/ujer.2019.071119.

[15] Rose, S M "What are some key attributes of effective online teachers?" Journal of Open, Flexible and Distance Learning, vol. 22, no. (2), pp. 32-48, 2018.

[16] Young, S "Student views of effective online teaching in higher education," American Journal of Distance Education, vo. 20 , no. 2 , pp. $65-77,2006$. https://doi.org/10.1207/s153 89286ajde2002_2 (Assessed online July 5, 2020).

[17] Cargile-Cook, K, K. Grant-Davie, "Online education 2.0: Evolving, adapting, and reinventing online technical communication" Amityville, NY: Baywood, 2016.

[18] Dyer J O, Hudon A, Montpetit-Tourangeau K, Charlin B, Mamede S, T. van Gog, "Example-based learning: Comparing the effects of additionally providing three different integrative learning activities on physiotherapy intervention knowledge" BMC Medical Education, vol. 15, no. 1, 2015. https://doi.org/10.1186/s12909-015-0308-3 (Assessed online June 23, 2020).

[19] Lehman R M, S. C. O. Conceição, "Motivating and retaining online students: Research-based strategies that work". San Francisco, CA: Jossey-Bass, 2014.

[20] Yuan J, C. Kim, "Guidelines for facilitating the development of learning communities in online courses: Development of online learning communities," Journal of Computer Assisted Learning, vol. 30, no. 3, pp. 220-232.https://doi.org/10.111 $1 /$ jcal. 12042

[21] Keengwe J, T. T. Kidd, "Towards best practices in online learning and teaching in higher education," MERLOT Journal of Online Learning and Teaching, vol. 6, no. 2, pp. $533-541,2010$.

[22] Rao K, A. Tanners, "Curb cuts in cyberspace: Universal instructional design for online courses," Journal of Postsecondary Education and Disability, vol. 24, no. 3, pp. 211-229, 2011.

[23] Crichton H, A. McDaid, "Learning intentions and success criteria: Learners' and teachers' views'" Curriculum Journal, vol. 27, no. 2, pp. 190-203, 2016. https://doi.org/10.1080/09585176.2015.1103278

[24] Woods R, Baker J, D. Hopper, "Hybrid structures: Faculty use and perception of web-based courseware as a supplement to face-to-face instruction," Internet and Higher Education, vol. 7, 281-297, 2004.

[25] Bradford P, Porciello M, Balkon N, B. Debra, "The Blackboard learning system: The be all and end all in educational instruction?" Journal of Educational Technology Systems, vol. 35, no. 3, pp. 301-314, 2007.

[26] Martin F, "Blackboard as the learning management system of a computer literacy course," MERLOT Journal of Online Learning and Teaching, vol. 4, no. 2, pp. 138-145, 2008.

[27] Heirdsfield A, Walker S, Tambyah M, D. Beutel, "Blackboard as an online learning environment: what do instructor education students and staff think?" Australian Journal of Instructor Education, vol. 36, no, 7, pp. 1-17, 2011.

[28] Ismael S A, "Using the Blackboard in improving the quality of e-learning in Arab universities: Qatar University is an example," Proceedings of the 14th International Conference for quality in education and training (higher education, research and challenges of the knowledge society). Morocco, Casablanca, 2007.

[29] Wali M F, "The effectiveness of a web-based collaborative learning program in promoting instructors' competencies of adopting the e-learning technology in teaching," Unpublished Ph.D. thesis. Faculty of Education: Alexandria University; Alexandria: Egypt, 2010.

[30] Al-Kadri S, "The effectiveness of teaching physics online utilizing Blackboard in the achievement of physical concepts among students of Physics Department in the University," Journal of Educational Sciences,vol. 25 no. 1, pp. 179-203, 2013.

[31] Fageeh A, M. Mekheimer, "Effects of Blackboard on EFL academic writing and attitudes," The JALTCALL Journal, vol. 9, no. 2, pp. 169-196, 2013.

[32] Al-Mohaidat R, A. Al-Barakat, "The effectiveness of blended learning based on the historical approach in improving student comprehension of science nature and the conceptual change in chemistry teaching environments," Islamic university Journal of Educational and Psychological Studies, Gaza, vol. 24, no. 3, pp. 83-107, 2016.

[33] AbdelAziz G, "The impact of e-learning level in teaching courses using learning management system "Blackboard on the academic achievement and the students' learning competence," Arabic studies in Education and Psychology, vol. 52, no. 2, pp. 113-158, 2014.

[34] Al-Shahri A. L. Mohamed, "The effectiveness of a training program for students of College of Education in Najran University on Blackboard and their attitudes towards it. The International Educational Specialized Journal, vol. 3, no. 7, pp. 19-41, 2014

[35] Al-Jabry H, Salahuddin M, A. Al-Shazly, "Developing and piloting a literature course learnable via Blackboard for EFL literature instruction". Studies in Literature and Language, vol. 8 , no. $1,85-95,2014$.

[36] Al-Agami L, "The impact of teaching according to electronic courses on the development of information research skills among female students of College of Education in King Khalid University," The international Journal of Educational Research, The United Arab Emirates University, vol. 138, pp. 146-177, 2015.

[37] Hussain E T, "The Effectiveness of Using Blackboard in Improving the English Listening and Speaking Skills of the Female Students at the University of Hail," Advances in Social Sciences Research Journal, vol. 3, no. 12, pp. 81-93, 2016. DoI:10.14738/assrj.312.2379.

[38] Al-Otaibi W H, "The Effectiveness of Blackboard-Based Blended Teaching in the Development of Academic Achievement, Study Skills and Self-Confidence among Students of Princess Nourah bint Abdulrahman University," International Education Studies, vol. 10, no. 11, pp. 100-115, 2017. doi:10.5539/ies.v10n11p100. URL: https://doi.org/10 $.5539 /$ ies.v10n $11 \mathrm{p} 100$

[39] Al-Zahrani M M, S. S. Al-Jraiwi, "Effectiveness of using Blackboard and collaborative tools in promoting practical skills among students of the foundation year in E-learning course. British Journal of Education, vol. 5, no. 4, pp. 19-53, 
2017.

[40] Elsawy A M, O. S. Ahmed, "E-Learning using the Blackboard system in Light of the Quality of Education and Cyber security. International Journal of Current Engineering and Technology, vol. 9, no. 1, pp. 49-54, 2019.

[41] Pinsonneault A, K. L. Kraemer, "Survey research methodology in management information systems: An assessment. Journal of Management Information Systems, vol. 10, pp. 75-105, 1993.

[42] Mathers N, Fox N, A. Hunn, "Surveys and Questionnaires," The NIHR RDS for the East Midlands / Yorkshire \& the Humber, The University of Sheffield, Sheffield", pp. 48. 2009.

https://www.rds-yh.nihr.ac.uk/wp-content/uploads/2013/05/ 12 Surveys and Questionnaires_Revision_2009.pdf (Accessed Jan 20, 2020).

[43] Backhouse J K, Dickins G L, Rayner S E, M J. Wood, "Choice of mathematics for A level," Oxford, United Kingdom: University of Oxford, Department of Educational Studies, 1982.

[44] Frazer C, Sullivan D H, Weatherspoon D, L. Hussey, "Faculty Perceptions of Online Teaching Effectiveness and Indicators of Quality," Nursing Research and Practice, vol. 1, no. 6, Article ID 9374189, 2017. https://doi.org/10.1155/20 17/9374189.

[45] Bao W, "Covid-19 and online teaching in higher education:
A case study of Peking University," Hum Behav \& Emeg Tech, vol. 2, pp. 113-115, 2020. DOI: 10.1002/hbe2.191

[46] Lervik M J, Vold T, S. Holen, "Conditions for Cooperating and Dialogue through the Utilization of Technology in Online Education," Universal Journal of Educational Research, Vol. 6, No. 10, pp. 2352 - 2363, 2018. DOI: 10.13189/ujer.2018.061034.

[47] Xhaferi G, Farizi A, R. Bahiti, "Teacher'attitudes towards e-learning in higher education in Macedonia Case study: University of Tetovo," European Journal of Electrical Engineering and Computer Science, vol. 2, no. 5, pp. 14-17, 2018. http://dx.doi.org/10.24018/ejece.2018.2.5.26

[48] Willett J, Brown C, L A. Danzy-Bussell, “An exploratory study: Faculty perceptions of online learning in undergraduate sport management programs," Journal of Hospitality, Leisure, Sport \& Tourism Education, vol. 25, 100206, 2019. https://doi.org/10.1016/j.jhlste.2019.100206

[49] Cuaton G P, "Philippines higher education institutions in the time of COVID-19 pandemic," Revista Românească pentru Educație Multidimensională, vol. 12, no. 1, pp. 61-70, 2020. https://lumenpublishing.com/journals/index.php/rrem/articl e/view/2761 (Accessed on July 15, 2020).

[50] Moralista R, R M. Oducado, "Faculty Perception Toward Online Education in Higher Education during the Coronavirus Disease 19 (COVID-19) Pandemic". Preprint 1-14. Preprint Doi: 10.31219/osf.io/nhr7b https://doi.org/10 .31219/osf.io/nhr7b (Accessed July 18, 2020). 